\title{
Rehun hiilihydraattikoostumuksen vaikutus porsaiden ruoansulatukseen
}

Pasi Laurinen ${ }^{1}$, Helle Nygaard Laerke ${ }^{2}$, Mette Skou Hedemann ${ }^{2}$, Carsten Pedersen ${ }^{3}$, Jan Erik Lindberg $^{3}$, Knud Erik Bach Knudsen ${ }^{2}$, Tarja Pohjanvirta ${ }^{4}$, Sinikka Pelkonen ${ }^{4}$, Paula Hyvönen ${ }^{5}$, Atte von Wright ${ }^{5}$.

${ }^{I}$ MTT (Maa-ja elintarviketalouden tutkimuskeskus), Kotieläintuotannon tutkimus, Sikatalous, Tervamäentie 179,05840 Hyvinkää etunimi.sukunimi@mtt.fi

${ }^{2}$ Danish Institute of Agricultural Sciences, Department of Animal Nutrition and Physiology, P.O. Box 50,8830 Tjele, Denmark, etunimi.sukunimi@agrsci.dk

${ }^{3}$ Swedish Agricultural University, Department of Animal Nutrition and Management, P.O. Box 7024, S-75007 Upsala, Sweden, etunimi.sukunimi@huv.slu.fi

${ }^{4}$ EELA, Kuopion tutkimusyksikkö,PL 92, 70701 Kuopio, etunimi.sukunimi@eela.fi

${ }^{5}$ Kuopion yliopisto, Soveltavan biotekniikan instituutti, PL 1627, 70211 Kuopio, etunimi.sukunimi@uku.fi

\section{Johdanto}

Vieroitettaessa porsaat joutuvat kohtaamaan useita stressitekijöitä. Porsaat siirretään uuteen karsinaan ja samalla mikrobiologisesti ja lämpöolosuhteiltaan uuteen ympäristöön. Ravinto vaihtuu rasvaa ja valkuaista sisältävästä emakon maidosta kasviperäiseen, pääasiassa hiilihydraatteja sisältävään kiinteään rehuun. Tästä johtuen porsaiden koko ruoansulatuskanavan toiminta muuttuu ja osa porsaista sairastuu ripuliin. Aikaisemmin vieroitusripulin torjunnassa on käytetty $\mathrm{mm}$. antibioottisia rehun lisäaineita, mutta niiden käyttö on nykyisin kielletty EU:n ja kansallisin säännöksin. Tällä hetkellä vieroitusripulia pyritään torjumaan mm. orgaanisilla hapoilla ja rehun koostumusta optimoimalla.

Rehun hiilihydraattikoostumus vaikuttaa paljon ruoansulatuskanavan ja sen mikrobiston kehitykseen. Tähän perustuu $\mathrm{mm}$. teoria prebiottien vaikutustavasta ripulin ehkäisyssä. Hiilihydraattien vaikutus porsaiden ruoansulatuskavanan kehitykseen ja terveyteen tunnetaan vielä hyvin huonosti ja tutkimustulokset ovat ristiriitaisia (Thacker 1999). Tutkimuksissa rehun hiilihydraatit ovat vaikuttaneet porsaiden ohutsuolen villuksen korkeus/kryptan syvyys suhteeseen (McDonald ym. 2001a), rehun viipymäaikaan suolistossa, mikrobiaktiivisuuteen, haihtuvien rasvahappojen määrään sekä suhteisiin ja digestan happamuuteen suolistossa (Freire ym. 2000). Choctin ja Kocherin (2000) mukaan suurimmassa osassa julkaistua kirjallisuutta nopeasti fermentoituvat oligosakkaridit stimuloivat suoliston hyödyllisiä mikrobeja. Göranssonin ym. (1995) mukaan raakakuitu ja sokerijuurikaskuitu vähentävät porsaiden ripulia, mutta McDonaldin ym. (2001b) mukaan fermentoituvat kuidut huonontavat porsaiden terveyttä ja lisäävät ripulia.

Kasvatuskoe on osa yhteispohjoismaista tutkimusprojektia (The interaction between dietary carbohydrates and digestive process in piglets, NKJ-112), jonka tarkoituksena on selvittää rehun hiilihydraattikoostumuksen, erityisesti ravintokuidun, kemiallisten ominaisuuksien vaikutusta porsaiden suoliston toimintaan, kehitykseen ja mikrobistoon, suolen sisällön fysio-kemiallisiin ominaisuuksiin, porsaiden terveyteen, kasvuun ja rehun hyväksikäyttöön sekä eri tyyppisten hiilihydraattien sulavuuteen ruoansulatuskanavan eri osissa.

\section{Aineisto ja menetelmät}

Koe tehtiin keskimäärin 30.8 (keskihajonta 2.1) pv:n iässä vieroitetuilla porsailla. Porsaat olivat karsinoissa pareittain. Käsittelyä kohti oli 12 porsasparia. Koe kesti 32 päivää. Kokeessa hyvin vähän kuitua sisältäneen rehuseoksen (ohrasuurimo, Paakarin ohrasuurimo, rikottu, Melia, $216 \mathrm{~g} / \mathrm{kg}$, vehnäjauho, Paakarin puolikarkea, Melia, $540 \mathrm{~g} / \mathrm{kg}+$ valkuais- ja kivennäis-vitamiinilisät) kuitupitoisuutta suurennettiin lisäämällä siihen ohrankuoria (96 tai $191 \mathrm{~g} / \mathrm{kg}$ ) tai pektiiniä (Genu Pectin 150 grade USA-SAG type B rapid set, PC Kelco ApS, $71 \mathrm{~g} / \mathrm{kg}$ ) tai kumpaakin kuitulähdettä yhdessä (kuoria 96 ja pektiiniä $71 \mathrm{~g} / \mathrm{kg}$ ) ohrasuurimoiden ja vehnäjauhon kustannuksella. Koska pektiini sisälsi sokeria, lisättiin muihin rehuihin vastaava määrä taloussokeria. Valkuaislähteenä käytettiin heraproteiinia ja kalajauhoa. Rehuseosten aminohappolisäykset tehtiin tanskalaisten, kokonaissulavuuteen perustuvien normien mukaan. Jauhemaisia rehuseoksia ja vettä oli porsaille vapaasti tarjolla. Rehunkulutus määritettiin viikoittain. Sontanäyte otettiin karsinoittain E. coli- ja maitohappobakteerien määrittämiseksi viiden päivän kuluttua vieroituksesta sekä kokeen päättyessä. 


\section{Tulokset ja tulosten tarkastelu Rehun syönti ja porsaiden kasvu}

Kuitulähteiden lisääminen onnistui rehuihin hyvin. Rehujen ravintokuitupitoisuus nousi ja oli kuitutason sisällä lähes sama (taulukko). Pektiininä rehuun lisätty liukoinen kuitu vähensi rehun syöntiä ja siten porsaiden kasvua. Syönnin vähentyminen näkyi myös Ruotsissa samoilla rehuilla tehdyssä kokeessa (Pedersen ym. 2003). Rehun kuitupitoisuuden nosto, varsinkin ei-liukoisella kuidulla, vähentää rehun energia-arvoa. Suuremmat siat pystyvät tietyissä rajoissa kompensoimaan täyttävän rehun tuottamaa haittaa syömällä enemmän, mutta porsailla ruuansulatuskanavan tilavuuden uskotaan rajoittavan syöntiä. Liukoinen kuitu lisää ruokasulan viskositeettiä, mistä liukoisen kuidun rehun hyväksikäyttöä huonontavien vaikutuksien uskotaan osittain johtuvan. Sioilla viskositeetin ja kuitulisien vaikutus ruoansulatukseen on kuitenkin paljon pienempi kuin siipikarjalla (Choct ja Kohler 2000). Porsailla viskositeetin suurentumisesta tiettyyn rajaan asti saattaa jopa olla hyötyä (McDonald ym. 2001a). Montagnen ym. (2003) mukaan liukoinen kuitu pidentää ruokasulan viipymäaikaa, hidastaa mahalaukun tyhjentymistä ja ravintoaineiden imeytymistä suolistosta sekä saattaa huonontaa ravintoaineiden sulavuutta. Liukoisen kuidun ruuansulatutusta hidastavat ominaisuudet ovat mahdollisesti vaikuttaneet rehun syöntiä vähentävästi. Syönnin alentuessa myös porsaiden kasvu huononi. Porsaat eivät tottuneet liukoiseen kuituun. Kuitulajin vaikutus päivittäin syötyyn rehumäärään suureni kokeen kuluessa kun porsaiden kokoero suureni. Kuitenkin suuremmat porsaat (alkupaino $15.8 \mathrm{~kg}$ ) ovat noin neljässä viikossa tottuneet liukoiseen kuituun (frukto- ja tarns-galaktooligosakkarideja) ja siitä eteenpäin syöneet kuituisia rehuja enemmän. Oligosakkaridit huononsivat porsaiden päiväkasvua kolmen ensimmäisen viikon aikana, mutta koko kuuden viikon jaksolla kasvussa ei ollut eroa (Houdijk ym. 1998). Paljon liukoista kuitua sisältävä sokerijuurikasleikelisä $(150 \mathrm{~g} / \mathrm{kg})$ ohrapohjaiseen rehuun ei vaikuttanut porsaiden rehun syöntiin tai kasvuun (Longland ym. 1994). Pektiinivalmisteiden vaikutus porsaiden kasvuun on riippunut pektiinin tyypistä ja alkuperästä (Pedersen ym. 2001). Rehuseoksen kuitupitoisuuden suurentaminen korvaamalla kaikki vehnä ohralla tai osa vehnästä sokerijuurikasleikkeellä huononsi syöntiä ja kasvua vain kokeen alussa, mutta keskimäärin rehu ei vaikuttanut syöntiin tai kasvuun eikä porsaiden painossa neljän viikon kuluttua vieroituksesta ollut eroja (Gill ym. 2000).

Vastoin yleistä käsitystä (Montagne ym. 2003) ohrankuorina lisätty ei-liukoinen kuitu ei vaikuttanut millään tavalla rehunsyöntiin eikä myöskään porsaiden kasvuun. Kuituinen rehu saattaa lisätä ruuansulatuskanavan osuutta kasvusta, koska kuituinen rehu vaatii enemmän sulatustyötä ja suolen sisällön määrä kasvaa. Tästä syystä päiväkasvu ei välttämättä huonone, vaikka kasvusta pienempi osa on tyhjän ruhon kasvua (Mcdonald ym. 2001a). Porsailla ei-liukoisen kuidun lisäämistä rehuun on tutkittu hyvin vähän. Vehnälese ja ruohojauho ovat huonontaneet porsaiden päiväkasvua (Lindberg ym. 1995). Lihasioilla ohrankuorien lisääminen rehuun ei vaikuttanut kasvuun, mutta teurastappio suureni ja lihaprosentti laski (Bell ja Keith 1994).

\section{Ripulisuus ja sonnan mikrobit}

Rehun kuitupitoisuus tai kuidun laatu yksistään ei vaikuttanut porsaiden ripulisuuteen, mutta rehuseos, jossa oli runsaasti liukoista ja ei-liukoista kuitua (sisälsi sekä ohran kuoria että pektiiniä) vähensi porsaiden ripulisuutta huomattavasti. Pektiini vähensi rehun syöntiä, minkä uskotaan vähentävät ripulia. Se ei yksin selitä ripulisuuden vähentymistä, koska pelkkä pektiinilisä ei vaikuttanut ripuliin ja vähensi samalla tavoin syöntiä. Ohrankuoret ja pektiini muodostivat mahdollisesti hyvän yhdistelmän, joka toimi kaikkialla suolistossa edistäen terveen suoliston kehittymistä. Liukoinen kuitu vaikuttaa jo ohutsuolessa, mutta ei-liukoinen kuitu vaikuttaa pääasiassa vasta paksusuolessa, jossa rehun viipymäaika on paljon pidempi ja mikrobiaktiivisuus suurempi (Hansen ym. 1992). Varsinkin liukoisen kuidun ja helposti fermentoituvien hiilihydraattien tehoa ripulin vähentämiseksi on tutkittu paljon, mm. erilaiset prebiotit kuuluvat tähän ryhmään. Kuidun vaikutus on ollut hyvin vaihteleva ja riippuu mm. siitä, mistä jyvän osasta kuitu on peräisin (Montagne ym. 2003). Göranssonin ym. (1995) mukaan sekä raakakuitupitoisuuden nostaminen ja sokerijuurikaskuitu vähentävät porsaiden ripulia, mutta australialaisten tutkimusten (McDonaldin ym. 1999, 2001a, 2001b, Hopwood ym. 2002) mukaan fermentoituvat kuidut edistäisivät E. colin ja/tai Brachyspira pilosicolin kasvua suolistossa ja lisäisivät ripulia. Meidän kokeessamme ruokinnat eivät vaikuttaneet E. coleihin eikä hemoloyyttisten pesäkkeiden määrään viisi päivää vieroituksen jälkeen eikä kokeen lopussa. Kokeen lopussa E. colien määrä oli vain vähän pienempi kuin alussa, mutta hemolyyttisten pesäkkeiden määrä väheni hyvin paljon. Sonnan E. coli määrä tai hemolyyttisten pesäkkeiden osuus ei selittänyt ripulia, vaikka E. colia 
pidetään ripulia aiheuttavana mikrobina (Bertshinger 1995). Sonnan E. coli määrä ei kuitenkaan kerro sitä, erosiko E. colien määrä paksusuolen alussa tai ohutsuolessa (Svendsen ym. 1977).

Ruokinta ei vaikuttanut sonnan maitohappobakteerien määrään viisi päivää vieroituksen jälkeen. Kokeen lopussa pelkkä pektiinilisä alensi maitohappobakteerien määrää, kun määritys tehtiin laktobasilleille selektiivisellä Rogosa-alustalla. MRS-agar alustalla määritettäessä eroa ei kuitenkaan ollut. Sonnan maitohappobakteerien määrä oli kokeen lopussa samalla tasolla kuin kokeen alussa.

\section{Johtopäätökset}

Kuitupitoisuus sinänsä ei vaikuttanut rehunsyöntiin, porsaiden kasvuun tai ripulisuuteen, vaan kuidun laatu vaikutti enemmän. Liukoinen kuitu vähensi rehunsyöntiä ja sitä kautta kasvua. Ohrankuorina lisätty ei-liukoinen kuitu ei vaikuttanut syöntiin eikä päiväkasvuun. Ripulisuus oli alhaisin rehulla, jossa oli sekä liukoista että ei-liukoista kuitua. Sonnan E. coli- tai maitohappobakteerimäärät eivät selittäneet ripulisuutta.

Koerehujen hiilihydraattikoostumus sekä kuitutason ja lajin $(\mathrm{OK}=$ ohrankuoret, $\mathrm{P}=$ pektiini) vaikutus porsaiden kasvuun rehunsyöntiin ja sonnan mikrobeihin.

\begin{tabular}{|c|c|c|c|c|c|c|c|}
\hline \multirow{2}{*}{$\begin{array}{l}\text { Kuitutaso } \\
\text { Kuitulaji } \\
\end{array}$} & \multirow[t]{2}{*}{ Matala } & \multicolumn{2}{|c|}{ Keskimääräinen } & \multicolumn{2}{|c|}{ Korkea } & \multirow[t]{2}{*}{ SEM } & \multirow[t]{2}{*}{ p-arvo } \\
\hline & & $\mathrm{OK}$ & $\mathrm{P}$ & $\mathrm{OK}$ & $\mathrm{P}+\mathrm{OK}$ & & \\
\hline \multicolumn{8}{|l|}{ Koostumus, g/kg ka } \\
\hline Tärkkelys & 585 & 527 & 522 & 490 & 494 & & \\
\hline Ravintokuitu $^{1}$ & 73 & 104 & 104 & 147 & 143 & & \\
\hline $\begin{array}{l}\text { Liukenemattomat ei-tärkkelys- } \\
\text { polysakkaridit }\end{array}$ & 25 & 53 & 28 & 82 & 75 & & \\
\hline $\begin{array}{l}\text { Liukoiset ei-tärkkelyspoly- } \\
\text { sakkaridit }\end{array}$ & 40 & 31 & 58 & 37 & 49 & & \\
\hline \multicolumn{8}{|l|}{ Porsaiden kasvu ja syönti } \\
\hline Alkupaino (vieroitus) & 9,32 & 9,63 & 9,44 & 9,51 & 9,20 & 0,45 & \\
\hline Loppupaino & $20,1 \mathrm{~b}$ & $20,1 \mathrm{~b}$ & $16,4 \mathrm{a}$ & $20,3 \mathrm{~b}$ & $17,4 \mathrm{a}$ & 1,0 & $* * *$ \\
\hline Päiväkasvu & $334 \mathrm{~b}$ & $325 \mathrm{~b}$ & $217 \mathrm{a}$ & $337 \mathrm{~b}$ & $254 \mathrm{a}$ & 22 & $* * *$ \\
\hline Rehuhyötysuhde & $1,79 \mathrm{a}$ & $1,81 \mathrm{a}$ & $2,13 \mathrm{~b}$ & $1,75 \mathrm{a}$ & $1,84 \mathrm{a}$ & 0,08 & $* * *$ \\
\hline \multicolumn{8}{|l|}{ Syönti, g/pv } \\
\hline keskimäärin & $564 \mathrm{~b}$ & $584 \mathrm{~b}$ & $428 \mathrm{a}$ & $582 \mathrm{~b}$ & $462 \mathrm{a}$ & 35 & $* * *$ \\
\hline 0-11 pv vieroituksesta & $268 \mathrm{~b}$ & $283 \mathrm{~b}$ & $194 \mathrm{a}$ & $256(a) b$ & $210 \mathrm{ab}$ & 23 & $* * *$ \\
\hline $11-18 \mathrm{pv}$ vieroituksesta & $504 \mathrm{~b}$ & $499 \mathrm{~b}$ & $380 \mathrm{a}$ & $529 \mathrm{~b}$ & $439 \mathrm{ab}$ & 36 & $* *$ \\
\hline $18-25 \mathrm{pv}$ vieroituksesta & 713(a)bc & $754(\mathrm{~b}) \mathrm{c}$ & $558 \mathrm{a}$ & $754(\mathrm{~b}) \mathrm{c}$ & $607 \mathrm{ab}$ & 60 & $* *$ \\
\hline $25-35$ pv vieroituksesta & $967 \mathrm{~b}$ & $972 \mathrm{~b}$ & $710 \mathrm{a}$ & $990 \mathrm{~b}$ & $735 \mathrm{a}$ & 58 & $* * *$ \\
\hline \multicolumn{8}{|l|}{ Ripulisuus, pv yhteensä } \\
\hline Ei ripulia & 315 & 310 & 317 & 314 & 361 & & $* * *$ \\
\hline Puuromainen uloste & 23 & 29 & 33 & 41 & 11 & & - \\
\hline Vellimäinen uloste & 34 & 36 & 26 & 26 & 9 & & - \\
\hline Vesiripuli & 5 & 9 & 8 & 3 & 3 & & - \\
\hline \multicolumn{8}{|l|}{ Sonnan mikrobit } \\
\hline \multicolumn{8}{|l|}{5 pv vieroituksesta } \\
\hline E. coli, $\log \mathrm{cfu} / \mathrm{g}$ sontaa & 8,20 & 8,10 & 8,28 & 8,12 & 7,96 & 0,23 & \\
\hline Hemmolyyttisiä pesäkkeitä, \% & 40,9 & 56,5 & 44,8 & 42,3 & 50,5 & 12,4 & \\
\hline \multicolumn{8}{|l|}{ Maitohapppbakteerit, cfu/g } \\
\hline Rogosa-alusta & 7,10 & 7,17 & 6,77 & 6,95 & 7,12 & 0,32 & \\
\hline MRS-Agar alusta & 8,79 & 8,71 & 8,64 & 8,98 & 8,73 & 0,17 & \\
\hline \multicolumn{8}{|l|}{ Kokeen lopussa } \\
\hline E. coli, log cfu/g sontaa & 7,13 & 7,06 & 7,26 & 6,20 & 7,00 & 0,37 & \\
\hline $\begin{array}{l}\text { Näytteessä ei lainkaan hemo- } \\
\text { lyyttisiä pesäkkeitä, kpl/n }\end{array}$ & $11 / 12$ & $11 / 12$ & $9 / 12$ & $11 / 12$ & $11 / 12$ & & - \\
\hline Maitohapppbakteerit, cfu/g & & & & & & & \\
\hline Rogosa-alusta & 7,22 & 6,95 & 6,39 & 6,84 & 6,53 & 0,25 & $*$ \\
\hline MRS-Agar alusta & 9,13 & 9,21 & 8,87 & 9,31 & 8,74 & 0,21 & \\
\hline
\end{tabular}

${ }^{1}$ Ravintokuitu = ei-tärkkelys polysakkaridit + Klason ligniini

Sarakkeet, joilla eri yläindeksi, eroavat toisistaan tilastollisesti merkitsevästi: $\mathrm{p}<0.05$, suluissa $\mathrm{p}<0.10$.

p-arvo - = vaikutusta ei ole testattu 


\section{Kirjallisuus}

Bell, J.M., Keith, M.O. 1994. Effects of adding barley hulls and linseed meal to wheat and hulless barley diets fed to growing pigs. Anim. Feed Sci. Technol. 45: 177-191.

Bertschinger, H.U. 1995. Pathogenesis of porcine post-weaning Eschrichia coli diarrhoea and of oedema disease. Review Article. Pig News and Information 16: 85N-88N.

Choct, M. \& Kocher, A. 2000. Proceedings of the 24th Annual Meeting of the Nutrition Society of Australia. pp. 31-38. Saatu http://www-personal.une.edu.au/ mchoct/Nutsoc\%20paper.pdf

Freire, J.P.B., Guerreiro, A.J.G., Cunha, L.F. \& Aumaitre, A. 2000. Effect of dietary fibre source on total tract digestibility, caecum volatile fatty acids and digestive transit time in the weaned piglet. Anim. Feed Sci. Technol. 87: 71-83.

Gill, B.P., Melange, J., Rooke, J.A. 2000. Growth performance and apparent nutrient digestibility in weaned piglets offered wheat-, barley- or sugar-beet pulp-based diets supplemented with food enzymes. Anim. Sci 70: 107-118.

Göransson, L. Lange, S. \& Lönnroth, I. 1995. Post Weaning diarrhoea: focus on diet, review article. Pigs News and Information 16: 89N-91N.

Hansen, I., Bach Knudesn, K.E., eggum, B.O. 1992. Gastrointestinal implications in the rat of wheat bran, oat bran and pea fibre. Br. J. Nutr. 68: 451-462.

Hopwood, D.E., Pethick, D.W., Hampson, D.J. 2002. Increasing the viscosity of the intestinal contents stimulates proliferation of enterotoxigenic Escheriachia coli and Brachyspira pilosicoli in weaner pigs. Br. J. Nutr. 88: 523-532.

Houdijk, J.G.M., Bosch, M.W., Verstegen, M.W.A., Berenpas, H.J. 1998. Effect of dietary oligosaccharides on the growth performance and faecal characteristics of young growing pigs. Anim. Feed Sci. Technol. 71: $35-$ 48.

Lindberg, J.E., Thomke, S. Anderson, C. 1995. Practical implications of using fibrous feeds in diets for pigs. 46 annual meeting of EAAP, Praha, 4.-7.9.1995, Paper N2.3.

Longöand, A.c., Carruthers, J., Low, A.G. 1994. The ability of piglets 4 to 8 weeks old to digest and perform on diets containing two contrasting sources of non-starch polysaccharide. Amin. Prod. 58: 405-410.

McDonald, D.E., Pethick, D.W., Mullan, B.P., Hampson, D.J. 1999. Adverse effect of soluble non-starch polysacharide (guar gum) on piglet growth and experimental colibacillosiss immediately after weaning. Res. Vet. Sci. 67: 245-250.

McDonald, D.E., Pethick, D.W., Mullan, B.P., Hampson, D.J. 2001a. Increasing viscosity of the intestinal contents alters small intestinal structure and intestinal growth, and stimulates proliferation of enterotoxigenic Escheria coli in newly-weaned pigs. Br. J. Nutr. 86: 487-498.

McDonald, D.E., Pethick, D.W., Mullan, B.P., Pluske, J.R., Hampson, D.J. 2001b. Soluble non-strach polysaccharides from pearl barley exacerbate experimental postweaning colibacillosis. In: Lindberg, J.E. 6 Ogle, B. (eds.), Digestive physiology of Pigs. Proceedings of the 8th Symposiusm. pp. 280-282.

Montagne, L., Pluske, J.R. \& Hampson, D.J. 2003. A review of interactions between dietary fibre and the intestinal mucosa, and their consequences on digestive health in young non-ruminant animals. Anim. Feed Sci. Technol. 108: 95-117.

Pedersen, A.Ø, Jensen, B.B., Bach Knudsen, K.E., Nygaard Larke, H.N. 2001. Pectin for weaners. Report $\begin{array}{lllll}\text { no. } 501 & \text { Abstrakti. } & \text { Saatu } & 4.6 .2002\end{array}$

http://www.danskeslagterier.dk/view.asp?ID=1161\&tID=687\&print=Dcpp

Pedersen, C., Nygaard Laerke, H., Lindberg J.-E., Hedemann M.S., Laurinen, P., Bach Knudsen, K.E. 2003. Digestibility and performance in newly weaned piglets fed diets with contrasting fibre levels and fibre properties. Proceedings of the 9th international symposium on digestive physiology in pigs, May 14-18., 2003, Banff, AB, Kanada. Volume 2, short communications. p. 128-129.

Svendsen, J., Riising, HJ.-J., Christensen, S. 1977. Studies on the pathogenesis of enteric E. colli infections in weaned pigs: bacteriological and immunofluorescent studies. Nord. Vet.-Med. 29: 212-220.

Thacker, P.A. 1999. Nutritional requirements of early weaned pigs: A review. Pig News and Information 20: $13 \mathrm{~N}-24 \mathrm{~N}$ 